\section{Method and Timing of Tuber De-eyeing Affects Growth and Development of Caladium}

\author{
Michael R. Evans and Brent K. Harbaugh \\ University of Florida, Institute of Food and Agricultural Sciences, Gulf Coast \\ Research and Education Center, Bradenton, FL 34203
}

Additional index words. Caladium $\times$ hortulanum, apical dominance

Abstract. Before being forced as potted plants, tubers of two Caladium xhortulanum Birdsey cultivars were subjected to different methods of de-eyeing (terminal bud removal), either before or after 6 weeks of curing and storage. The cultivar Frieda Hemple ('FH'), a type with numerous buds that does not require de-eyeing, was less affected by deeyeing than 'Fannie Munson' ('FM'), which has a single dominant bud and requires deeyeing. De-eyeing had little effect on 'FH' development. For 'FM', regardless of the time of de-eyeing, all treatments reduced height, increased the number of leaves, increased total leaf area, and reduced mean leaf area when compared to intact tubers. However, as the size of the tuber piece removed during de-eyeing increased, the variability within each treatment increased. Based on the results of this research, the best method of de-eyeing would be to destroy or remove the dominant terminal bud while removing as little of the surrounding tissue as possible. The time of de-eyeing can depend on producer preference, since the time of de-eyeing did not affect development significantly.

Caladium, a native of the tropical Americas (Liberty Hyde Bailey Hortorium, 1976), has become a significant floricultural crop throughout the world as a landscape and potted plant (Evans et al., 1992). Caladiums are propagated commercially and forced from tubers. Depending on the cultivar, caladium tubers may form a single or several dominant terminal buds surrounded by secondary buds or may form tubers with buds of similar size (Evans et al., 1992). Tall shoots with a few large leaves develop from the dominant buds, and these tend to inhibit the development of the secondary buds.

Terminal bud removal (de-eyeing) has been reported to reduce plant height, increase the number of leaves produced, and increase uniformity (Conover and Poole, 1975). Although de-eyeing is commonly recommended for caladium used as potted plants or as landscape border plants (Black and Tija, 1979; Harbaugh and Tija, 1985; Wilfret, 1984), to our knowledge, no caladium research reports the effects of method or time of de-eyeing on subsequent plant growth and development. The objective of this research was to determine the optimal method and time of de-eyeing caladiums.

A 2-year study was conducted to determine the effects of de-eyeing on caladium growth and development. However, because

\footnotetext{
Received for publication 19 Mar. 1993. Accepted for publication 8 June 1993. published as Florida Agricultural Experiment Station journal series R03045. We thank Happiness Farms and Bates and Sons Caladiums for financial and material support of this project. Use of trade names does not imply endorsement of the products named nor criticism of similar ones not named. The cost of publishing this paper was defrayed in part by the payment of page charges. Under postal regulations, this paper therefore must he hereby marked advertisement solely to indicate this fact.
}

the second-year study included all variables examined in the first year, and the results for both years were similar, only the second-year study is presented. 'Frieda Hemple' ('FH') and 'Fannie Munson' ('FM') caladiums were used in this study. 'FH' tends to have many uniform-sized buds (terminal and secondary buds are a similar size), and de-eyeing is not recommended (Evans et al., 1992) for plants produced in $15-\mathrm{cm}$ pots or used in landscape border plantings. 'FM' has a single dominant bud, and de-eyeing is recommended for potted plant and border plant production. Tubers used in this study were produced in Lake Placid, Fla. Harvest and initial tuber treatments were conducted 12 Dec. 1991. Immediately after harvest, tubers were washed and sorted by size. All tubers selected for this study were 3.8 to $6.3 \mathrm{~cm}$ in diameter (commercially classified as number one size tubers) and had a single terminal bud.

This study employed two de-eyeing times in factorial combination with six de-eyeing treatments. Tubers were either de-eyed immediately after harvest (before curing and storage) or after curing and storage. Regardless of treatments, all tubers were cured at $27 \mathrm{C}$ for 1 week and then stored at $21 \mathrm{C}$ for 5 weeks before planting. De-eyeing treatments included intact controls (no treatment); tubers that had the terminal bud destroyed by piercing the bud with a 3-mm-diameter metal probe; tubers that had the bud removed using a no. 11 surgical blade (Feather Surgical Blades; Fisher Scientific, Pittsburgh), but with as little of the tubers' starchy flesh removed as possible (flicked); or tubers that had a 7-, 9-, or 13-mmdiameter $\times 5$-mm-deep cylinder, containing the terminal bud, removed using cork borers.

Tubers were planted in $15-\mathrm{cm}$-diameter (1.7-liter) containers filled with a pasteurized planting medium composed of 1 Florida peat
$: 1$ fine sand: 1 vermiculite (v/v) and amended with (in $\mathrm{kg} \cdot \mathrm{m}^{-3}$ ) 5.9 dolomitic limestone, 3 hydrated lime, 0.6 superphosphate with frits (FTE-503), and 5.9 Nutricote 13N-5.7P-10.8K slow-release fertilizer (Plantco, Bramalea, Ont., Canada). Tubers were planted upright and $\approx 2.5 \mathrm{~cm}$ below the medium surface. Plants were spaced on 20 -cm centers and watered using a subirrigation capillary mat system. Plants were forced in a glasshouse with a night minimum of $21 \mathrm{C}$ and under a photosynthetic photon flux of 625 to $710 \mu \mathrm{mol}^{-2-1} \cdot{ }^{-1}$ at 1200 HR. The number of days to emergence of the first leaf was recorded, and, 10 weeks after planting, plant height, leaf fresh weight, number of leaves, total leaf area, and leaf size were recorded. A complete randomized block design was used with two plants per treatment per block and 12 blocks. However, no significant effect due to block occurred, so the data were analyzed as a completely randomized design. Significance of the main factors and interactions were determined by analysis of variance, and where significant differences occurred, differences between means were determined using a least significant differences test.

De-eyeing, regardless of method or time, had no significant effect on the days to emergence for either 'FH' (35 to 43 days) or 'FM' (38 to 40 days). Plant height was not affected significantly by de-eyeing for 'FH' (Table 1). Although all methods of de-eyeing significantly reduced plant height for 'FM', the time of de-eyeing was not significant. No significant interaction occurred between method and time of de-eyeing with respect to plant height, so only the main effects are shown.

Data for leaf growth did not follow the assumption of equal variances among treat-

Table 1. Effect of method and timing of de-eyeing on subsequent growth and development of two caladium cultivars.

\begin{tabular}{lcc}
\hline & \multicolumn{2}{c}{ Ht (cm) } \\
\cline { 2 - 3 } $\begin{array}{l}\text { Method and time } \\
\text { of de-eyeing }\end{array}$ & $\begin{array}{c}\text { Frieda } \\
\text { Hemple }\end{array}$ & $\begin{array}{c}\text { Fannie } \\
\text { Munson }\end{array}$ \\
\hline Method $^{y}$ & & \\
Intact & 18 & 20 \\
Probe & 18 & 15 \\
Flick & 17 & 17 \\
Cylinder (mm) & & \\
7 & 19 & 15 \\
9 & 17 & 14 \\
13 & 19 & 15 \\
Significance & NS & $* *$ \\
LSD $(\alpha=0.05)$ & --- & 3 \\
Time & & \\
Before curing & 18 & 16 \\
After curing & 17 & 15 \\
Significance & NS & NS \\
LSD $(\alpha=0.05)$ & --- & -- \\
\hline
\end{tabular}

2Probe indicates tubers that had the terminal bud destroyed by piercing the bud with a 3-mm-diameter probe. Flick indicates tubers that had the terminal bud removed with a blade while removing as little of the starchy portion of the tuber as possible. The 7-, 9-, and 13-mm treatments had the respective-sized diameter piece removed to a depth of $5 \mathrm{~mm}$.

'Interactions were nonsignificant; therefore, data were analyzed over main effects of method and time.

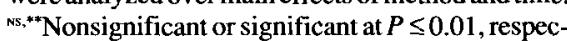
tively. 
ments as determined by Hartley's test for homogeneity of population variances $(\alpha=$ $0.05, \mathrm{~F}_{\max }=9.01$ ); therefore, the means and standard errors are presented for these variables (Table 2). For discussion purposes, means are considered significantly different if they differ from one another by plus or minus the standard error of the treatment mean as compared to the intact control.

Although there was a trend of increasing fresh weight when tubers were de-eyed, particularly when de-eyed after curing, neither the total. leaf count nor the fresh weight of the leaves were consistently significantly affected by de-eyeing for 'FH' (Table 2). However, compared to control plants, the leaf count was consistently increased for 'FM' when tubers were de-eyed, regardless of method or time. The time of de-eyeing did not significantly affect leaf count for 'FM'. There were no consistent significant differences in leaf counts or fresh weights between the de-eyeing methods or times for either cultivar.

For 'FH', the standard errors for leaf count and fresh weight were either similar among treatments or increased as the portion of the tuber removed during de-eyeing increased. For 'FM', the standard errors for leaf count and fresh weight remained constant or decreased when tubers were de-eyed using the probe or flick methods, but increased as the size of the removed portion of the tuber increased during de-eyeing. Time of de-eyeing had no consistent effect on the standard errors for these variables.

For 'FH', de-eyeing by the probe and 7$\mathrm{mm}$-diameter cylinder resulted in an increase in total leaf area when conducted before curing, although the increase was significant only for the 7-mm cylinder (Table 2). Although not significant, de-eyeing by the flick, 9-mm, or 13-mm methods reduced total leaf area when conducted before curing. When de-eyeing was conducted after curing, no method affected total leaf area significantly; however, total leaf area was largest with the probe method.

For 'FM', de-eyeing resulted in an increase in the total leaf area regardless of method or time as compared to the control. For both times, the total leaf area was largest with the flick method and was reduced as the size of the portion of the tuber removed during de-eyeing increased (Table 2). When de-eyed by the flick and 7-mm methods, total leaf area was larger when de-eyeing was conducted before rather than after curing.

The standard errors for total leaf area increased for both cultivars with increasing size of the portion of the tuber removed during deeyeing. The smallest standard errors usually resulted from the probe or flick methods.

The de-eyeing method did not significantly affect mean leaf area for 'FH' when conducted after curing. However, when conducted before curing, the probe and 7-mm. methods increased leaf area for 'FH' (Table 2). For 'FM', all de-eyeing treatments reduced leaf area when compared to controls. As the size of the portion of the tuber piece removed during de-eyeing increased, the leaf area was reduced further. De-eyeing after curing reduced leaf area more than de-eyeing before curing. For both cultivars, increasing size of the portion of the tuber removed during de-eyeing was associated with increasing standard errors, with the smallest standard errors resulting from the probe and flick methods.

De-eyeing affected the development of 'FH' less than 'FM', probably because the central bud of 'FH' was less dominant and exerted less control over the secondary buds, and because the 'FH' buds were more uniform in size than 'FM' buds. These results are consistent with commercial recommendations, which require de-eyeing for 'FM' but not for 'FH' (Evans et al., 1992). An interesting result is that de-eyeing did not reduce leaf count in 'FH'. Therefore, since de-eyeing removed potential leaves (by destruction or removal of the terminal bud), additional shoots, or additional leaves per shoot, that did not develop in control plants must have been produced as a result of de-eyeing. Such production would indicate that the difference between 'FH' and
'FM' is in the degree of dominance exerted by the terminal bud, and that, although many secondary shoots emerge in 'FH' without deeyeing, some buds still fail to develop unless tubers are de-eyed.

As reported previously (Conover and Poole, 1975; Harbaugh and Tija, 1985), de-eyeing reduced plant height, reduced leaf area, and, for some de-eyeing methods, increased uniformity. However, based on this research, the de-eyeing method and cultivar are important for determining the effect of de-eyeing on caladium development. Further, the de-eyeing method also affected the population variability. As the size of the portion of the tuber removed during de-eyeing increased, the standard error became greater. Since the degrees of freedom are equal for all treatments, the standard error serves as an indicator of the variability within a treatment. Thus, although many de-eyeing treatments had horticulturally desirable effects based on the means, increasing the severity of the de-eyeing treatment increased the variability within a treatment. The increase invariability with increasing severity of de-eyeing may have resulted from any or all of the following: 1) increased damage to the tuber, 2) removal of small secondary buds that surrounded the terminal bud, or 3) removal of root initials that exist on the surface of the tuber surrounding the buds. Regardless of the cause, the increased variability with increasing severity of de-eyeing is important from a horticultural standpoint, because it is unacceptable to sacrifice uniformity for increased quality (i.e., reduced plant heights, reduced leaf size, and increased leaf area) in a portion of the crop. Based on these results, deeyeing should be conducted so that the terminal bud is destroyed or removed while removing as little as possible of the tuber's surrounding starchy flesh. Since the time that de-eyeing was conducted did not have a consistently significant effect on plant development, the practice of de-eyeing could be conducted either before or after curing and storage, depending on producer preference.

Table 2. Effect of method and time of de-eyeing on subsequent development of leaves for two caladium cultivars.

\begin{tabular}{|c|c|c|c|c|c|c|c|c|}
\hline \multirow{3}{*}{$\begin{array}{l}\text { Cultivar } \\
\text { and de-eyeing } \\
\text { method }^{2}\end{array}$} & \multicolumn{8}{|c|}{ Leaves } \\
\hline & \multicolumn{2}{|c|}{ Total count } & \multicolumn{2}{|c|}{ Fresh wt (g) } & \multicolumn{2}{|c|}{ Total area $\left(\mathrm{cm}^{2}\right)$} & \multicolumn{2}{|c|}{ Mean area $\left(\mathrm{cm}^{2}\right)$} \\
\hline & $\begin{array}{l}\text { Before } \\
\text { curing }\end{array}$ & $\begin{array}{c}\text { After } \\
\text { curing }\end{array}$ & $\begin{array}{l}\text { Before } \\
\text { curing }\end{array}$ & $\begin{array}{c}\text { After } \\
\text { curing }\end{array}$ & $\begin{array}{l}\text { Before } \\
\text { curing }\end{array}$ & $\begin{array}{c}\text { After } \\
\text { curing }\end{array}$ & $\begin{array}{l}\text { Before } \\
\text { curing }\end{array}$ & $\begin{array}{c}\text { After } \\
\text { curing }\end{array}$ \\
\hline \multicolumn{9}{|l|}{ Frieda Hemple } \\
\hline Intact & $10(2)$ & $11(2)$ & $29(4)$ & $29(3)$ & $668 \quad(84)$ & $655 \quad(70)$ & $68 \quad(5)$ & $70(6)$ \\
\hline Probe & $10(2)$ & $12(2)$ & $31(3)$ & $30(3)$ & 754 (74) & $708 \quad(88)$ & 81 (6) & $65(6)$ \\
\hline Flick & $10(1)$ & $12(1)$ & $25(4)$ & $32(3)$ & $594 \quad(84)$ & $601(80)$ & $71(10)$ & $73(6)$ \\
\hline \multicolumn{9}{|c|}{ Cylinder (mm) } \\
\hline 7 & $11(2)$ & $11(2)$ & $37(4)$ & $35(4)$ & 861 & $640(100)$ & $82(9)$ & $72(9)$ \\
\hline 9 & $11(2)$ & $12(2)$ & $26(5)$ & $34(4)$ & $539(100)$ & $697(101)$ & $59(12)$ & $60(12)$ \\
\hline 13 & $10(2)$ & $11(3)$ & $33(4)$ & $35(4)$ & $579(102)$ & $675(108)$ & $60(18)$ & $56(14)$ \\
\hline \multicolumn{9}{|l|}{ Fannie Munson } \\
\hline Intact & $3(3)$ & $4(3)$ & $30(4)$ & $31(3)$ & $652(153)$ & $681(120)$ & $294(15)$ & $270(10)$ \\
\hline Probe & $8(2)$ & $9(2)$ & $39(4)$ & $33(3)$ & $1151(111)$ & $1016(152)$ & $154(10)$ & $108(12)$ \\
\hline Flick & $8(2)$ & $10(2)$ & $42(3)$ & $36(3)$ & $1249(120)$ & $1026(107)$ & $160(13)$ & $125(9)$ \\
\hline \multicolumn{9}{|c|}{ Cylinder $(\mathrm{mm})$} \\
\hline 7 & $10(3)$ & $10(3)$ & $40(5)$ & $39(5)$ & $1223(137)$ & $934(135)$ & $121(12)$ & $102(11)$ \\
\hline 9 & $8(4)$ & $11(3)$ & $34(5)$ & $35(4)$ & $989(170)$ & $967(143)$ & $122(16)$ & $98(12)$ \\
\hline 13 & $8(4)$ & $12(3)$ & $36(5)$ & 34 (5) & $1111(182)$ & $923(179)$ & $136(16)$ & $90(12)$ \\
\hline
\end{tabular}

2Probe indicates tubers that had the terminal bud destroyed by piercing the bud with a 3-mm-diameter probe. Flick indicates tubers that had the terminal bud removed with a blade while removing as little of the starchy portion of the tuber as possible. The 7-, 9-, and 13-mm treatments had the respective-sized diameter piece removed to a depth of $5 \mathrm{~mm}$. Due to unequal variances between treatments, data presented are means with standard errors in parentheses. 


\section{Crop Production}

\section{Literature Cited}

Black, R.J. and B. Tija. 1979. Caladiums for Florida. Florida Coop. Ext. Serv. Circ. 469.

Conover, C.A. and R.T. Poole. 1975. Influence of fertilizer level, apical bud removal and tuber orientation on forcing of Caladium bicolor. HortScience 10:226-227.
Evans, M.R., G.J. Wilfret, and B.K. Harbaugh. 1992. Caladiums as potted and landscape plants. Florida Coop. Ext. Serv. Circ. 1060.

Harbaugh, B.K. and B.O. Tija. 1985. Commercial forcing of caladiums. Florida Coop. Ext. Serv. Circ. 621.
Liberty Hyde Bailey Hortorium. 1976. Hortus third: A concise dictionary of plants cultivated in the United States and Canada. 3rd ed. Macmillan, New York.

Wilfret, G.J. 1984. Caladiums to know and grow. Foliage Dig. 7(7): 1-3. 